\title{
TINJAUAN TERHADAP PRODUKSI BIODIESEL DARI MINYAK GORENG CURAH DENGAN METODE GELOMBANG ULTRASONIK DAN MICROWAVE
}

\author{
AGUS LUKMAN HAKIM \\ Politeknik Negeri Sriwijaya \\ agus.hakim@yahoo.com
}

\section{Abstrak}

Biodiesel adalah produk bahan bakar ramah lingkungan, yang dihasilkan dalam proses transesterifikasi yaitu reaksi antara metanol dan trigliserida, produk sampingan yang dihasilkan adalah gliserol. Keunggulan biodiesel dibandingkan bahan bakar fosil adalah tingkat emisi yang rendah, tidak beracun, terbarukan dan biodegradabel. Dengan metode konvensional, untuk menghasilkan biodiesel yang menggunakan biaya pengadukan listrik dan mekanik banyak biaya dengan tagihan listrik karena reaksi transesterifikasi membutuhkan waktu lebih dari satu jam untuk menyelesaikan reaksinya. Metode alternatif untuk memproduksi biodiesel dengan menghemat penggunaan sumber daya listrik dan waktu dengan gelombang ultrasonik, gelombang mikro atau gabungan dari dua metode. Metode gelombang ultrasonik telah banyak digunakan dalam proses transesterifikasi pembuatan biodiesel yang meningkatkan perpindahan massa antara alkohol dan trigliserida. Penyinaran gelombang mikro adalah salah satu metode pemanasan yang digunakan untuk mengurangi waktu reaksi dan konsumsi listrik dibandingkan dengan pemanasan konvensional. Jika kedua metode digabungkan maka akan didapat hasil produk yang tinggi.

\section{Abstract}

Biodiesel is an environmentally friendly fuel product, generated in the transesterification process ie the reaction between methanol and triclyceride, a by-product produced by glycerol. The advantages of biodiesel compared to fossil fuels are low emmision level, non-toxic, renewable and biodegradable. In conventional method, to produce biodiesel which used electrical and mechanical stirring cost a lot cost by electric bill because transesterification 
reaction takes more than one hours to complete the reaction. An alternative method for producing biodiesel by saving the use of electrical and time resources by ultrasonication, microwaves irradiation or combined methods of the two methods. Sonification methods have been widely used in the transesterification process of making biodiesel which increases the mass transfer between alcohol and triglicerides. Microwaves irradiation is one of the heating methods used to reduce reaction time and electricity consumption compared to conventional heating. If the two methods are combined then the product will get high yield.

Keywords : biodiesel, transesterification reaction, ultrasonic, microwave irradiation

\section{PENDAHULUAN}

\section{Latar Belakang}

Seiring dengan bertambahnya jumlah penduduk, peningkatan pertumbuhan ekonomi, berkembangnya dunia industri terutama industri otomotif di tanah air maka permintaan bahan bakar terutama bahan bakar fosil semakin meningkat. Meningkatnya permintaan tersebut tidak diiringi dengan ketersediaan bahan bakar fosil di dalam negeri dan pada tahun 2004 Indonesia resmi menyandang sebagai negara net importir minyak dunia. Indonesia harus mengimpor 350.000 barel per hari untuk mencukupi kebutuhan dalam negeri nya, sebagian besar diimpor dari negara Arab, Afrika dan Rusia. 


\section{KONSUMSI BBM NASIONAL PER TAHUN}

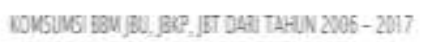

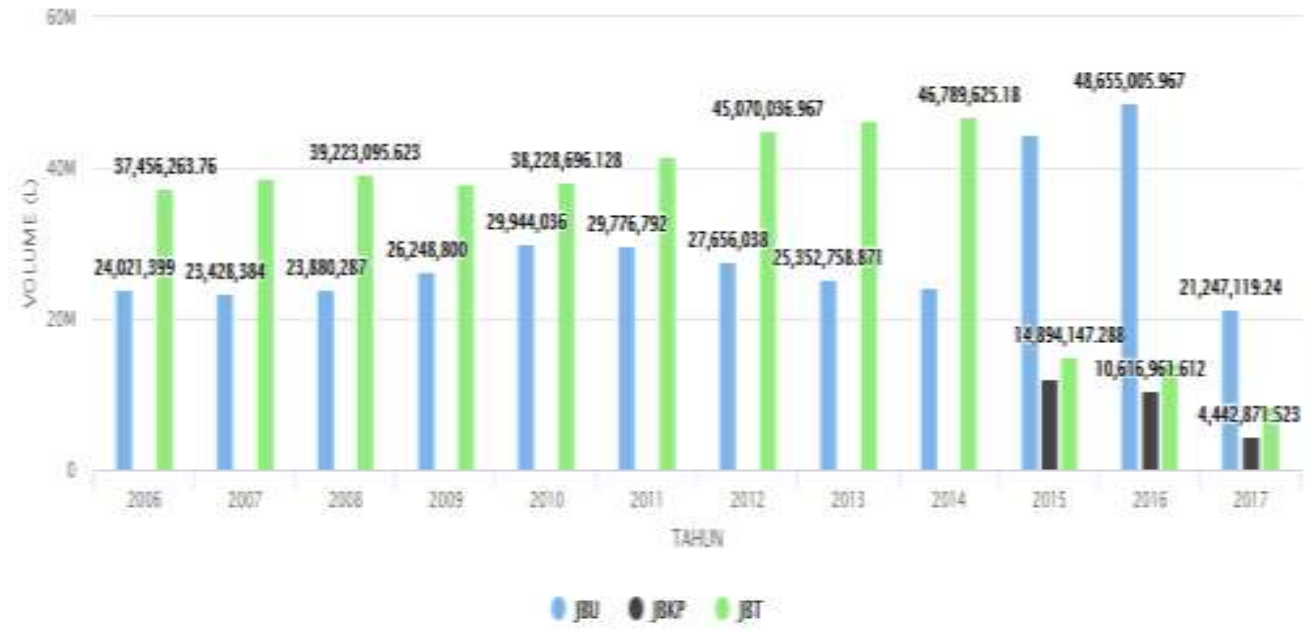

Gambar 1. Konsumsi BBM Nasional dari Tahun 2006 - 2017

(sumber : http://www.bphmigas.go.id/konsumsi-bbm-nasional, data 2017 baru diinput sampai bulan Juli)

Sejumlah langkah diambil pemerintah untuk menahan laju pemakaian bahan bakar fosil antara lain dengan penghematan pemakaian listrik di sejumlah gedung-gedung pemerintahan, pembatasan pemakaian kendaraan dinas, pengkonversian bahan bakar minyak tanah ke LPG, pengkonversian bahan bakar mobil dari bensin ke gas, pengembangan teknologi nuklir, pembatasan jumlah penumpang untuk kendaraan mobil (3 in 1), pemakaian solar sel untuk pengatur lalu lintas sampai pengembangan energi baru dan terbarukan antara lain pemanfaatan energi panas bumi, energi angin, energi matahari, energi air, energi pasang-surut air laut, energi dari tumbuhan seperti biomassa dan biodiesel. Biodiesel semakin dilirik oleh pemerintah dan sektor swasta karena Indonesia sebagai salah satu penghasil minyak sawit terbesar di dunia berpotensi sangat besar untuk mengembangkan bahan bakar jenis ini. 
Pertamina sebagai instansi yang diberi wewenang untuk memproduksi dan menyalurkan bahan bakar di Indonesia sudah memproduksi secara masal jenis B5 yang artinya 5\% bahan bakar nabati dan 95\% bahan bakar fosil.

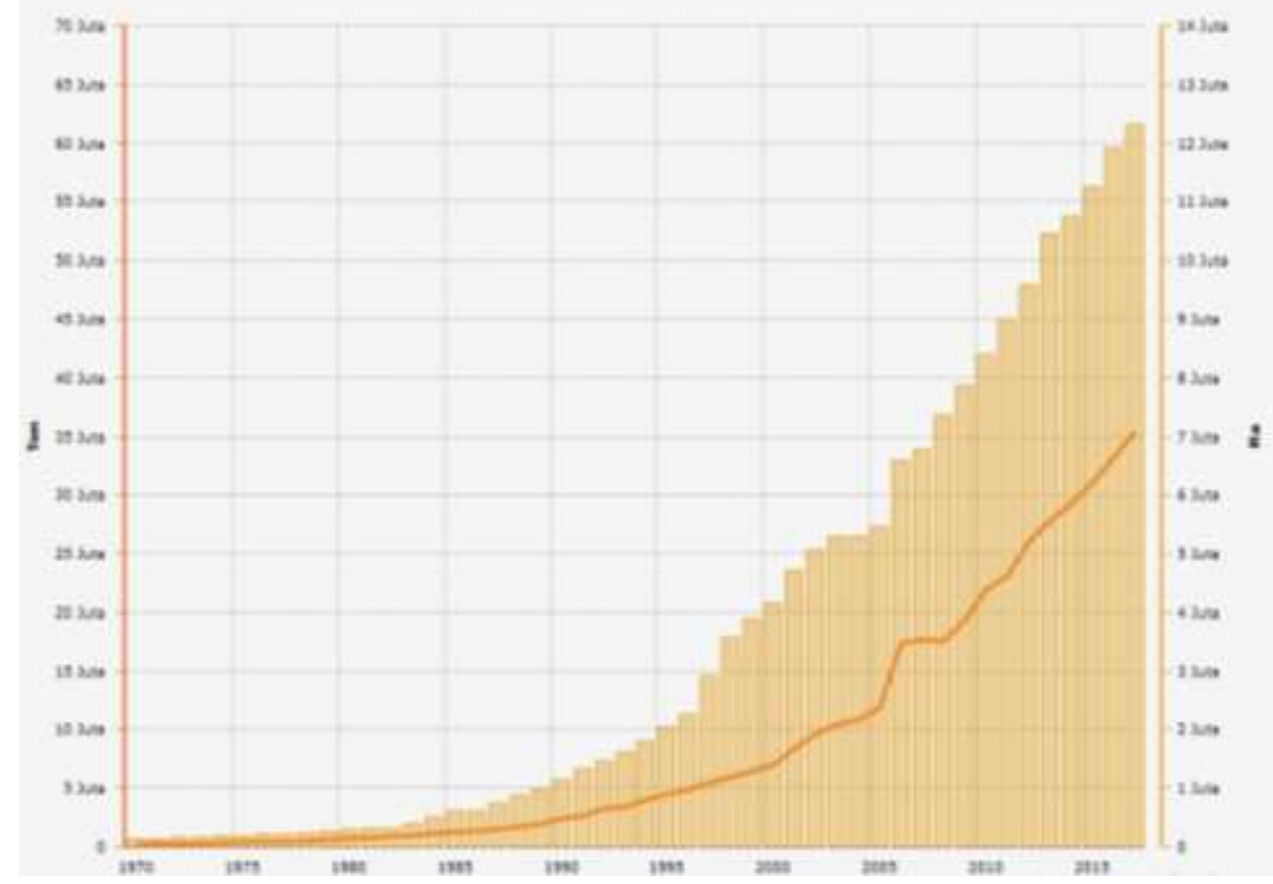

Gambar 2. Kapasitas Produksi dan Luas Lahan Perkebunan Sawit di Indonesia

(Sumber : https://databoks.katadata.co.id/datapublish/2017/10/10/berapa-produksiminyak-sawit-indonesia)

Dalam kurun waktu 10 tahun terakhir, pertumbuhan kapasitas dan luas lahan perkebunan sawit mengalami kenaikan yang signifikan. Pada tahun 2008, produksi minyak sawit hanya 19,2 juta ton dan pada tahun 2016 naik menjadi 32 juta ton, ada kenaikan $160 \%$ dalam kurun waktu delapan tahun terakhir.

Biodiesel merupakan produk dari reaksi transesterifikasi antara mono alkil ester (minyak dari tumbuh-tumbuhan dan lemak hewan) dengan alkohol (umumnya metanol dan etanol) dan produk samping yang dihasilkan berupa gliserol. Umumnya untuk memperbesar produk biodiesel digunakan katalis, baik yang berupa basa yaitu $\mathrm{NaOH}, \mathrm{KOH}, \mathrm{CaO}$ dan katalis yang berupa 
asam seperti $\mathrm{H}_{2} \mathrm{SO}_{4}$ dan $\mathrm{H}_{3} \mathrm{PO}_{4}$. Untuk terjadinya reaksi transesterifikasi maka dibutuhkan pengadukan dan perlakuan panas. Proses pengadukan secara konvensional menggunakan motor pengaduk dan memakan waktu yang lama (sekitar 1 jam lebih) dan perlakuan panas nya memakai alat hot plate. Dengan berkembang nya ilmu pengetahuan dan teknologi maka proses pengadukannya bisa dipersingkat dengan menggunakan gelombang ultrasonik dan untuk proses pemanasannya digunakan gelombang mikro. Proses yang tadinya memakan waktu lama sekarang bisa dipersingkat dalam hitungan menit.

Tabel 1. Syarat Mutu Biodiesel

\begin{tabular}{|c|c|c|c|}
\hline No & Parameter & Satuan & Nilai \\
\hline 1 & Massa jenis pada $40^{\circ} \mathrm{C}$ & $\mathrm{kg} / \mathrm{m}^{3}$ & $850-890$ \\
\hline 2 & Viskositas kinematik pd $40^{\circ} \mathrm{C}$ & $\mathrm{mm}^{2} / \mathrm{s}(\mathrm{cst})$ & $2,3-6,0$ \\
\hline 3 & Angka setana & & $\min .51$ \\
\hline 4 & Titik nyala (mangkok tertutup) & ${ }^{\circ} \mathrm{C}$ & $\min .100$ \\
\hline 5 & \begin{tabular}{|l|l|} 
Titk kabut \\
\end{tabular} & ${ }^{\circ} \mathrm{C}$ & maks. 18 \\
\hline$\overline{6}$ & $\begin{array}{l}\text { Korosi lempeng tembaga ( } 3 \text { jam pada } \\
50^{\circ} \mathrm{C} \text { ) }\end{array}$ & & maks. no 3 \\
\hline 7 & $\begin{array}{l}\text { Residu karbon } \\
\text { - dalam contoh asli } \\
\text { - dalam } 10 \% \text { ampas distilasi }\end{array}$ & $\%$-massa & maks 0,05 \\
\hline 8 & Air dan sedimen & $\%$-vol & maks $0,05^{*}$ \\
\hline 9 & Temperatur distilasi $90 \%$ & ${ }^{\circ} \mathrm{C}$ & maks. 360 \\
\hline 10 & Abu tersulfatkan & $\%$-massa & maks. 0,02 \\
\hline 11 & Belerang & $p \rho m-m(m g / k g)$ & maks. 100 \\
\hline 12 & Fosfor & $\mathrm{pom}-\mathrm{m}(\mathrm{mg} / \mathrm{kg})$ & maks. 10 \\
\hline 13 & Angka asam & $\mathrm{mg}-\mathrm{KOH} / \mathrm{g}$ & maks. 0,8 \\
\hline 14 & Gliserol bebas & $\%$-massa & maks. 0,02 \\
\hline 15 & Gliserol total & $\%$-massa & maks. 0,24 \\
\hline 16 & Kadar ester alkil & $\%$-massa & $\min .96,5$ \\
\hline 17 & Angka iodium & $\begin{array}{l}\% \text {-massa } \\
(\mathrm{g}-12 / 100 \mathrm{~g})\end{array}$ & maks. 115 \\
\hline 18 & Uji Halphen & & Negatif \\
\hline
\end{tabular}

Sumber : SNI Biodiesel 04-7182-200 


\section{METODOLOGI PENELITIAN}

\section{a. Jenis dan Metode Penelitian}

Jenis dan metode penelitian yang digunakan pada penulisan karya tulis ilmiah ini adalah studi literatur. Dimana, bahan-bahan yang di ambil berupa:

1. Jurnal penelitian mengenai aplikasi gelombang ultrasonik pada proses pembuatan biodiesel.

2. Jurnal penelitian mengenai aplikasi gelombang microwave pada proses pembuatan biodiesel.

3. Jurnal penelitian mengenai pembuatan biodiesel dari jarak pagar, minyak sawit, minyak jelantah, dan minyak biji karet.

\section{b. Objek dan Subjek Permasalahan}

Subjek permasalahan jurnal ini adalah pemanfaatan CPO sebagai bahan baku pembuatan biodiesel. Dan objek permasalahan dalam karya tulis ilmiah ini adalah penggunaan gelombang ultrasonik dan gelombang mikro untuk mendapatkan produk berupa biodiesel dengan nilai optimum.

\section{c. Sumber Data}

Adapun sumber data pada penulisan jurnal ini adalah data sekunder. Dimana data ini tidak diperoleh secara langsung dari sumbernya (data primer), misalnya wawancara dan observasi. Namun data sekunder ini diperoleh dari jurnal-jurnal penelitian terdahulu mengenai pembuatan biodiesel.

\section{d. Metode Pengumpulan Data}

Metode pengumpulan data pada penulisan karya ilmiah ini adalah studi pustaka. Dimana, studi pustaka merupakan metode pengumpulan data yang diarahkan kepada pencarian data dan informasi melalui dokumen-dokumen, baik dokumen tertulis, foto-foto, gambar, maupun dokumen elektronik yang dapat mendukung dalam proses penulisan. 


\section{e. Teknik Pengumpulan Data}

Adapun teknik pengumpulan data dalam penulisan karya ilmiah ini adalah teknik membaca, mencatat, dan menganalisis. Dimana bahan pustaka yang telah dikumpulkan dibaca terlebih dahulu kemudian mencatat bagian-bagian penting dari bahan pustaka sekaligus mengutip pendapat para ahli yang relevan dengan penelitian. Selanjutnya, data-data tersebut di analisis sehingga diperoleh kesatuan data yang memperkuat argumen penulis mengenai pembuatan biodiesel dari CPO menggunakan gelombang ultrasonik dan microwave.

\section{HASIL DAN PEMBAHASAN}

Biodiesel merupakan salah satu bahan bakar alternatif. Biodiesel dapat dibuat dari minyak sawit dan bahan baku lainnya. Katalis yang digunakan untuk reaksi Pembentukan Biodiesel tersebut dapat berupa katalis asam atau basa. Reaksi transesterifikasi baik yang menggunakan katalis asam atau basa membutuhkan panas. Pada proses pembuatan biodiesel secara konvensional, panas mengalir secara konveksi. Proses transesterifikasi merupakan bagian terpenting pada rangkaian proses produksi biodiesel dan berpengaruh pada proses pemurnian pasca reaksi. Microwave atau gelombang mikro telah lama digunakan sebagai metode pemanasan. Pemanasan dengan gelombang mikro mempunyai karakteristik yang berbeda dengan pemanasan konvensional, karena panas dibangkitkan secara internal akibat getaran molekul-molekul target oleh gelombang mikro. Karena karakter gelombang mikro yang dapat menembus molekul target, maka pemanasan dengan gelombang mikro berlangsung secara simultan. Hal ini berbeda dengan pemanasan konvensional, dimana panas mengalir dari sumber eksternal secara konveksi atau konduksi. Pemanasan seperti ini memerlukan energi yang besar dan waktu yang cukup lama. 
Sebelumnya telah dilakukan penelitian oleh Rhesa P. Putra dkk, mahasiswa ITS, melakukan penelitian dengan tujuan untuk membuat biodiesel dari minyak goreng dari kelapa sawit melalui proses transesterifikasi dengan menggunakan radiasi microwave secara batch serta mempelajari berapa daya dan waktu optimal yang diperlukan untuk proses pembuatan biodiesel dengan radiasi microwave dengan katalis $\mathrm{H}_{2} \mathrm{SO}_{4}, \mathrm{CaO}$ dan tanpa katalis. Metode yang digunakan dalam pembuatan biodiesel dari minyak goreng adalah proses reaksi transesterifikasi dengan menggunakan radiasi gelombang microwave. Bahan yang digunakan adalah minyak goreng yang berasal dari lemak tumbuhan yang sudah dimurnikan (mengalami proses penyulingan, dan penghilangan bau) dan berbentuk cair dalam suhu kamar. Minyak goreng yang digunakan dalam penelitian ini memiliki kandungan FFA sebesar 0,05\%. Dalam penelitian ini digunakan tiga variabel, yaitu daya (Watt): 100, 200, 300, 400; waktu (menit): 5, 10, 15, 20; dan jenis katalis: $\mathrm{CaO}, \mathrm{H}_{2} \mathrm{SO}_{4}$, dan tanpa katalis.

Pada tahap analisis, biodiesel dari hasil reaksi transesterifikasi dianalisa untuk mendapatkan data yield metil ester, densitas, viskositas, dan flash point. Dari penelitian diperoleh bahwa hasil yang didapatkan masih belum dapat memenuhi standar biodiesel yang ditetapkan karena reaktor tidak mampu beroperasi pada suhu dan tekanan tinggi. Katalis $\mathrm{CaO}$ dapat memberikan hasil yang lebih baik dibandingkan dengan katalis $\mathrm{H}_{2} \mathrm{SO}_{4}$ dan tanpa katalis. Kondisi operasi untuk menghasilkan kualitas yield biodiesel terbaik yaitu pada daya 200 Watt selama 20 menit dengan menggunakan katalis $\mathrm{CaO}$. Yield biodiesel terbesar didapatkan yield sebesar 60,11\%.

Gelombang ultrasonik akan menimbulkan peregangan dan pemampatan pada ruang antar cairan, sehingga menyebabkan terbentuknya gelembung mikro. 
Gelembung mikro berumur sangat singkat (kurang dari 1x 10-7 detik), dan ketika gelembung tersebut pecah, akan membantu mengecilkan ukuran droplet metanol maupun minyak menjadi $42 \%$ lebih kecil dibandingkan yang diperoleh dari metode konvensional. Hal ini menyebabkan jumlaharea antar muka kedua fase reaktan bertambah banyak, sehingga membantu proses pembentukan metil ester (biodiesel) yang lebih cepat.

Selain jurnal penelitian, penulis juga menganalisis penelitian dari Azharrudin (2016), analisa pengaruh persen yield biodiesel berbahan baku minyak jelantah ditinjau dari waktu reaksi dan pengaruh katalis $\mathrm{NaOH}$ dengan pemanfaatan gelombang mikro dan separasi tegangan tinggi dan penelitian dari Susila Arita (2013), Peluang dan Tantangan Komersialisasi BiodiselReview. Dimana penulis dapat menganalisis Dalam proses pembuatan biodiesel terdapat beberapa faktor yang mempengaruhi proses pemanasan yang terjadi, salah satunya adalah waktu reaksi. Pengaruh dari waktu reaski dapat dilihat dari hasil persen yield biodiesel yang didapat.

Dari hasil penelitian, waktu reaksi yang digunakan ialah 5, 10, 15 menit dengan temperatur tetap yaitu $55^{\circ} \mathrm{C}$, hasil yang didapat yaitu $85,737 \%$, $84,838 \%$, dan $84,441 \%$. hal ini dikarenakan kontak antar zat akan semakin banyak sehingga konversi semakin tinggi. Hal ini menunjukkan bahwa alat pembuatan biodiesel dengan pemanfaatan gelombang mikro dapat menghasilkan persen yield yang tinggi dengan waktu yang singkat, .Pengaruh dari variabel proses berupa jumlah katalis $\mathrm{NaOH}$ kondisi terbaik, yield maksimum dari biodiesel minyak jelantah adalah $74.45 \%$ yang didapat dengan menggunakan perbandingan mol minyak jelantah/methanol 1:6 pada suhu $60^{\circ} \mathrm{C}$ dengan waktu reaksi 10 menit dan katalis $\mathrm{NaOH} 1,5 \%$. 
Maka dari itu, produksi biodiesel dari minyak goreng curah dengan metode gelombang ultrasonik dan microwave ialah untuk mencari alternatif lain proses transesterifikasi tanpa menggunakan panas langsung.

\section{KESIMPULAN}

Pemakaian teknologi gelombang ultrasonik dan gelombang mikro pada proses pembuatan biodiesel lebih efektif dan efisien karena bisa mempercepat reaksi dari waktu sejam lebih sampai beberapa menit saja dan penghematan pemakaian sumber daya listrik.

Pemakaian katalis, baik asam maupun basa bisa mempercepat reaksi transesterifikasi dan yield produk yang dihasilkan bisa lebih tinggi.

\section{DAFTAR PUSTAKA}

Arita, S dkk. (2013) "Pembuatan Biodiesel dari Minyak Kelapa Sawit dengan Katalis $\mathrm{CaO}$ Disinari dengan Gelombang Mikro" Jurnal Teknik Kimia No. 4, Vol 19.

Azzharuddin dkk (2016) “Analisa Pengaruh Persen Yield Biodiesel Berbahan Baku Minyak Jelantah Ditinjau Dari Waktu Reaksi dan Pengaruh Katalis $\mathrm{NaOH}$ dengan Pemanfaatan Gelombang Mikro dan Separasi Tegangan Tinggi” Jurnal Kinetika Politeknik Negeri Sriwijaya.

Ji J, Wang J, Li Y, Yu Y, Xu Z. 2006. Preparation of Biodiesel With the Help of Ultrasonic And Hydrodynamic Cavitation. Ultrasonics 44:411-414

Rhesa, P dkk (2012) "Pembuatan Biodiesel Secara Batch dengan Memanfaatkan Gelombang Mikro” Jurnal Teknik ITS Vol.1 No. 1

Wu P, Yang Y, Colucci JA, Grulke EA. 2007. Effect of Ultrasonication on Droplet Size in Biodiesel Mixtures. J Am Oil Chem Soc. 84:877-884. 